\title{
The European Union: A Peace Actor in the Making? Reflections Based on the ESDP Crisis Management Operations in Africa
}

\author{
Kyriakos Revelas $^{1}$ \\ ${ }^{1}$ Senior Security Policy Analyst, European External Action Service, Brussels, Belgium \\ Correspondence: Kyriakos Revelas, Senior Security Policy Analyst, European External Action Service, \\ Charlemagne 12/87, Rue de la Loi 170, B-1046-Brussels, Belgium. E-mail: Kyriakos.Revelas@eeas.europa.eu
}

Received: March 12, 2013 Accepted: July 3, 2013 Online Published: July 5, 2013

doi:10.5539/res.v5n3p73 URL: http://dx.doi.org/10.5539/res.v5n3p73

The views expressed in this paper are strictly those of the author and not those of the European External Action Service.

\begin{abstract}
The article explores whether the EU has advanced as a peace actor since the inception of ESDP with respect to its comprehensive approach to peace building. An overview of EU (military and civilian) crisis management operations in Africa serves to address questions on planning, lessons learned, cooperation among EU member states and institutions and with international actors and the link to capability development. While the emerging picture is mixed, it seems fair to say that the EU actors have made significant progress in working together to achieve agreed objectives. Challenges still exist and call for further common efforts, but the experience gathered will help making the next steps towards consolidating EU "actorness" in this field. In particular, the systematic 'lessons learned' process introduced for ESDP operations as well as linking any lessons to capability development are positive features whose beneficial effects will likely continue to grow in future.
\end{abstract}

Keywords: EU operations, Africa, crisis management, peacebuilding

\section{Introduction}

From its beginnings in the 1950's following the tragic experience of the two World Wars, European integration has been described as a peace project that has led to creation of a security community (Deutsch et al., 1957). The European Union (EU) can thus be regarded as a peace actor by its very existence. However, in the conventional sense of an entity working toward supporting peace outside its own territory in conflict-ridden countries/regions, the EU began acting and being perceived as such by others much later. Indeed, it was only by 1999 that the EU developed the political will and means to become a peace actor. The European Security and Defence Policy (ESDP) is one of the latest policy developments in the European integration process and an integral part of the Common Foreign and Security Policy (CFSP) established with the Treaty of the European Union (Maastricht, 1992). ESDP (Note 1) was initiated in 1999 and has since evolved both in terms of dedicated institutions and structures, crisis management operations and corresponding capabilities (Howorth, 2007; Anderson, 2008).

Despite (or perhaps because of) the rapid development and enhanced visibility of EU action for peace and stability in other parts of the world, Union action in the crisis management field is still a work in progress and in some respects even an experiment as new forms of operations are launched and types of cooperation and synergies with other actors are actively pursued. This is due not only to the relatively short time span elapsed since the inception of ESDP, but also to a large extent to the character of the EU itself, which unlike other international actors is neither a state nor an international organisation, but a sui generis political construction. Moreover, and related to the nature of the EU as a complex, multilevel political actor, what distinguishes the Union's approach to peace and stability in its crisis management functions is its wide-ranging approach. This comprehensiveness has multiple dimensions: EU member states and institutions; the variety of instruments employed, which are governed by different institutional rules; interaction of field operations with local actors and international partners; the phases of the conflict cycle (conflict prevention, crisis management, post-conflict stabilisation and rehabilitation) during which an intervention occurs. 
These characteristics of EU action in peace support will be examined in this article, which addresses the following questions: Has the EU, in the first 10 years of ESDP, advanced as a peace actor? Have improvements in field operations occurred in keeping with the Union's comprehensive approach? More specifically, have intervention efforts improved? For example, are more recent operations better planned than earlier ones? Have problems encountered in early efforts been overcome? Is the EU systematically identifying lessons from its crisis management operations and ensuring that those are incorporated into its future actions? Has cooperation between EU institutions as well as between Union crisis management institutions and member states improved over time? Has the EU been able to demonstrate progress in exploiting synergies among the different instruments employed in interventions? Have these operations elicited cooperation and synergies between the EU and other actors? Has the Union been able to develop a link between crisis management efforts and relevant capability development? Given its focus, this analysis examines security governance structures, and does not consider the notion of security (Christou et al., 2010).

The article addresses these questions by examining a number of ESDP crisis management operations (CMO). The first ESDP operations were launched in 2003, and since that date a total of 25 crisis management operations have been deployed, of which 7 have been primarily military in character and 18 civilian or civil-military; 14 missions are ongoing; (Council of the EU, 2010a; Grevi, Helly, \& Keohane, 2009). Together with the Western Balkans, Africa has seen the largest number of EU CMO. Those interventions have also been among the more risky and challenging military operations to take place on the African continent in recent decades. Geographical proximity, long standing European links with Africa dating back to colonial times, strong EU engagement in development policy, frequent instances of state fragility and related security challenges are factors explaining the EU commitment in terms of ESDP missions in Africa (and in the neighbourhood countries more generally).

To date, the EU has launched 11 military and civilian ESDP missions in Africa. They will be described briefly here with a focus on a critical examination of what they reveal about the evolution and character of Union crisis management operations.

Assessment of crisis management operations presents methodological difficulties; many factors and actors are at play and contribute to the course of events that are beyond the influence of the particular crisis intervention. Conversely, when analysing an operation, its intended and unintended, direct and indirect as well as short and long-term effects should be taken into account. The criteria for that analytic purpose used are drawn from Asseburg and Kempin (2009, 14-15):

- Genesis of the ESDP mission mandate which includes the motivations of member states and EU institutions and their willingness to provide capabilities, forces and personnel;

- Mandate implementation dynamics;

- Mission effectiveness as measured against the political objectives of the peace actor (in the case of the EU the general objectives are formulated in the European Security Strategy, Council of the EU 2003 and 2008).

Operation cost effectiveness might represent an additional criterion, but data availability does not allow a systematic evaluation of the African interventions on that basis. The number and size of the deployed operations are probably not appropriate evaluation criteria, although relevant from a political perspective.

This argument is organized into several discrete parts. The paper first provides an overview and evaluation of EU crisis management operations in Africa with a particular focus on the questions outlined above. It then traces the evolution of ESDP operations. Thereafter, the analysis places those efforts into a broader policy context. The concluding section draws on the analysis offered in previous sections to contend that the EU as a peace actor is now entering a stage during which it is consolidating its approach and the capabilities necessary to attain those goals.

\section{Overview and Evaluation of ESDP Crisis Management Operations/Missions in Africa}

\section{Missions to the Democratic Republic of Congo}

A series of civil wars during the 1990s provided the backdrop to EU engagement in the Democratic Republic of Congo (DRC). Several neighbouring countries helped to launch a peace process that resulted in the Pretoria Agreement of December 2002. That accord created an interim government and a transitional process leading to national elections in 2006.

The Union undertook its Operation Artemis to the DRC at the request of the UN on very short notice. It sought to stabilise the security conditions and improve the humanitarian situation in the city of Bunia, province of Ituri, 
in the Eastern part of the DRC. The mission lasted for three months (June-September 2003) until the existing UN entity (MONUC) could be reinforced to address the situation. The EU deployed some 2,000 troops, mainly from France, but also from 13 other member states and three non-Union countries. Artemis was a reasonable success as it fulfilled its mandate, demonstrated good cooperation with the UN, put to test the concept of 'framework nation' and served as a model for rapid EU military response (Helly, 2009a).

The EU has deployed two police missions to the DRC since 2005 (Vircoulon, 2009). Launched at the request of the Congolese government, EUPOL Kinshasa (April 2005-June 2007) monitored, mentored and advised the country's Integrated Police Unit to help consolidate security in the capital. After the elections in 2006, the EU created a second police mission EUPOL DR Congo, (June 2007-today) to support efforts to reform the national police (PNC) and to ensure coherence among the three pillars of security sector reform (armed forces, police, justice). Following the Goma peace agreement for the Kivus in January 2008, the Union extended the EUPOL DR Congo deployment to both North and South Kivu. The two police missions demonstrated flexibility in a rapidly changing political context, while ensuring continuity. However, the missions have encountered coordination problems with the UN (UNPOL) and with other EU institutions. For example, the European Commission has provided the country assistance via the European Development Fund (EDF), which employs a 5 -year programming cycle with substantial funding, while EUPOL has worked within a one-year time frame and six-month mandates. Meanwhile, France and the UK have operated parallel bilateral programmes to support police reforms, in addition to being involved in EUPOL. Taking into account the involvement of non-EU actors in the country as well, these characteristics of development support have presented EUPOL leaders with a significant coordination challenge.

EUSEC DR Congo (May 2005-today) supports security sector reform (SSR), in particular the integration of the Congolese army. It is a civilian mission designed to provide advice for army reform (Clément, 2009). The Mission has realized several concrete achievements, including creation of a clear chain of military payments (separate from the chain of command) and a census of army personnel to tackle widespread corruption. With only modest strength, EUSEC has managed to place staff in relevant departments and ministries and has faced a number of challenges including different institutional contexts for Community aid instruments and CFSP/ESDP crisis operations. The Council and Commission together developed an overarching concept that has helped to overcome initial coordination difficulties. EUSEC staff members have also had to navigate internal Congolese political differences over the character and pace of army reform. Coordination with the UN mission has also proved difficult. More generally, SSR in a post-conflict environment is particularly challenging, as evidenced by the rebellion in 2008 in the East and the accelerated integration into the Congolese army in early 2009. EUSEC has not followed the usual pattern of donor activity by providing training and equipment, but has instead focused on helping to establish more effective personnel and resource management processes and on developing a strategic vision. While professionalism and personal contacts have helped with these efforts political backing for each has proved uneven.

Given the fragility and transitional character of the judicial sector in the country, the Commission, together with interested member states (Sweden and Belgium), has utilized the European Development Fund (40 million Euros) to support urgent justice reforms in the Eastern provinces as well as to sustain more general governance and justice support programmes,. In 2007-08 the Instrument for Stability provided an additional 18 million Euros for military brigade integration, to support the development of more effective national police human resource management systems and to help to stabilize conditions in the Eastern part of the country.

EUFOR DR Congo (30 July-30 November 2006) was deployed at the UN request to assist MONUC during the election process, to act as a deterrent and to protect civilians and the airport. (Major, 2009) Some 2,400 troops were deployed in Kinshasa and as an on-call force stationed in Gabon, while a strategic reserve stationed in Europe was available that could bring total mission strength to about 4,000 troops. Twenty-one member states as well as two non-EU countries contributed personnel to the effort. The overall cost of the operation is estimated at 100 million Euros (Note 2) at a time when overall assistance from the EU for DR Congo amounted to some 750 million Euros. Political agreement to proceed with the operation was relatively easy to obtain, but the force generation process proved lengthy. Germany accepted command of the OHQ (operational headquarter), while France provided the FHQ (force headquarter). Parliamentary approval in Germany led to a number of limitations on how the force could be used. Interaction with MONUC proved difficult due to overlapping mandates and the lack of a formal agreement for the exchange of classified information, which often led to differing threat assessments. EUFOR fulfilled its mandate without facing serious military challenges. The mission undertook stabilising tasks on three occasions and these proved decisive in containing the potential spread of violence at sensitive moments of the electoral process. While some have criticised the duration and geographic reach of the 
EUFOR mandate, the operation did fulfil its mandate and demonstrated EU capacity to act militarily in a distant theatre (Note 3).

\subsection{Mission to Sudan}

The EU supported the African Union (AU) mission in Sudan (AMIS) from its inception (Franke 2009). The current conflict in Darfur began in 2003 and escalated rapidly, leaving tens of thousands dead and millions displaced. Since the Sudanese government refused its consent to a UN mission, the AU launched an observer mission following the ceasefire agreement of April 2004. This effort (AMIS) was then successively reinforced in October 2004 and April 2005, before being replaced by a hybrid UN/AU mission (UNAMID) in December 2007. The EU supported the AU involvement throughout diplomatically, operationally and financially. Operational support included equipment, technical assistance and civilian and military personnel. Financial support included approximately 700 million Euros in humanitarian aid; and 30 million Euros in funding for capacity building and operational expenses through the African Peace Facility (APF funding came from the European Development Fund, see below) supplemented by more than 20 million in aid from individual member states. Despite the investment of these significant resources, peace could not be reached in Darfur. EU support has been important for the AU missions, but it has not been provided without limitations. APF funding has covered only a part of the initiative's overall cost and because development funds cannot finance military equipment, the mission has strongly emphasised training.

\subsection{Mission to Chad}

EUFOR Chad/CAR (Central African Republic) (15 March 2008-15 March 2009) complemented the United Nations mission MINURCAT and was charged to protect refugees / displaced persons, to facilitate the delivery of humanitarian aid and to protect UN personnel (Helly 2009b.) Beginning in 2006 France has sought to address the Darfur humanitarian crisis. Meanwhile, the UN was involved in difficult negotiations with the government of Sudan for a UN-AU operation. One way around the continuing stalemate was to act outside the Sudan territory. Accordingly, France proposed an ESDP mission in May 2007. EUFOR Chad/CAR was logistically the most complex operation launched to that date since it involved a recalcitrant and landlocked country. The mission's cost was high (estimated at 1 billion Euros, of which 120 million Euros were common costs) and the time period to generate the necessary force was lengthy. In the end, 23 member states and 3 non-EU countries contributed 3,700 troops to the mission. France, Ireland and Poland provided the largest numbers. After a difficult start (due to a rebel attack on the capital of Chad) and delays in the setup of the Chadian joint police and gendarmerie force which was to provide security for the refugee camps, good cooperation developed with the local government and the humanitarian community. The re-hating of a large percentage of the EUFOR troops smoothed the handover of the mission's responsibilities, including its FHQ, to the UN mission.

Political debate surrounding the EUFOR mission centred on its neutrality and impartiality, as some observers considered French motives ambiguous. The mission attained good coordination between the EU Council Secretariat and the European Commission. This was the first ESDP operation in which the Commission was involved in all phases, from initial fact finding to the lessons learned process. Using the EDF the Commission contributed funds for the protection of refugee camps and rehabilitation projects. It also supported the UN police mission (training). EUFOR fulfilled its mandate and provided security for the refugee camps (approximately 400,000 displaced persons), but its efforts do not seem to have positively influenced either the political situation in Chad or Chad/Sudan relations. Overall, EUFOR Chad/CAR was a useful experience for the EU. The framework nation concept proved useful and a kind of European security culture among participating officers began to develop. In theatre mobility was greatly enhanced by Russia's provision of helicopters. The huge logistical challenges were managed well and there was good technical EU/UN cooperation.

In contrast, Berg (2009) has strongly criticised the mission. In his view, EUFOR only touched upon symptoms and did not address the root causes of the crisis which the mission set out to help overcome. The protection of UN civilian personnel was achieved, but the security situation in camps actually deteriorated during the mission and displaced persons could not return safely. The EU presence effectively deterred the rebels from attacking the Chad government, but ethnic groups nonetheless frequently attacked civilians during the mission. Apart from being seen by many as serving mainly French interests, Berg argued that EUFOR seems to have overlooked an important lessons for peace support operations, namely that no military effort should be mounted without a political process and that long-term commitment is needed. However, one may ask whether such criticism can be applied to an operation outside the conflict country aimed at the protection of refugees and deployed precisely because a political process was not possible. 


\subsection{Mission to Guinea-Bissau}

EU SSR Guinea-Bissau (June 2008-September 2010) was deployed against the background of a nation that had endured military rule and civil war during most of its history since its independence in 1974 (Helly 2009c). In spite of the legitimacy of the army stemming from the war of liberation, ethnic cleavages and external destabilising factors negatively affected the country's security governance. A window of opportunity appeared following the election of 2005 to address this concern and the UK supported drafting a national strategy for security sector reform. Following a fact-finding mission (Secretariat of the EU Council and Commission) and the invitation of national authorities, the Joint Action launching the mission was adopted in February 2008. The operation's mandate was to assist the authorities in implementing the national strategy, to facilitate donor assistance for capacity building and to assess the relevance of continued ESDP engagement. From its inception, the mission had limited staff ( 21 advisors) and budget (up to 6 million Euros). Political instability and violence hampered its work as local interlocutors had been changing. The effort also suffered from poor communication of its objectives and lack of coordination with other actors in the international community. The operation remained understaffed and overstretched and did not manage to develop a strong spirit of cooperation with local partners.

The Commission supported the reform of state institutions and the creation of a pension fund for public employees. Further programmes are planned to support the justice sector and to improve civil and military administration effectiveness. Moreover, to combat illicit drug trafficking, the Commission supported training and equipment projects. The EU Stability Instrument meanwhile helped fund regional capacity building to fight organised crime along the cocaine route. Altogether, the EU expended more than 53 million Euros in support of the Guinea-Bissau mission.

\subsection{Missions to Somalia}

The EU supported the African Union (AU) mission in Somalia (AMISOM) launched in January 2007 under difficult conditions. Those challenges included political controversy, a disastrous humanitarian situation and a lack of funds, which led to chronic understaffing (Franke 2009). The Union announced its diplomatic, operational and financial support for AMISOM in April 2007. The EU seconded four experts to the mission's strategic planning and management unit (through the Stability Instrument) and facilitated deployment of the mission by paying troop allowances though the African Peace Facility (amounting to 95 million Euros). Member states complemented these initiatives with bilateral aid.

Piracy activity off the coast of Somalia and in the Gulf of Aden has intensified in recent years, against a background of political instability and lawlessness in the country. Attacks on aid deliveries by the UN World Food Programme destined for the Somali population in addition to raids on international transport and fisheries interests increased in number and severity just prior to the mission's launch. Meanwhile, pirate capture of a shipment of heavy weaponry and of a large oil tanker highlighted the risks related to terrorist activities and served as a symbol to trigger international community action (Helly 2009d). The EU launched a coordination cell dubbed NAVCO in September 2008, followed by the first-ever naval EU operation, EU NAVFOR Atalanta (December 2008-today). Nineteen member states have contributed to the mission with approximately 2000 personnel at an estimated cost of 400 million Euros annually with common costs of 8.4 million. The main objectives of Atalanta, not a typical crisis management operation, are to protect WFP and other merchant vessels from pirate attacks. The mission involves escorting specific vessels as well as monitoring and patrolling sea lanes and ship traffic in the Gulf of Aden. The operation also routinely engages in law enforcement measures including the arrest, detention and transfer of criminal suspects. The OHQ in Northwood, UK, hosts the Maritime Security Centre (MSC). The MSC provides a secure web-portal with services to merchant vessels. EU member nation naval officers and private business representatives jointly manage the Centre. Atalanta has created an internationally recommended transit corridor in its area of operations and the registration rate of affected vessels had increased to some $70 \%$ by mid- 2009 .

Weber (2009) has argued that Germany was the driving force behind Atalanta as its commercial interests were worst affected since $92 \%$ of its trade occurs by sea. Meanwhile, France has long maintained a military base in Djibouti. With the deployment of the mission the delivery of humanitarian supplies improved, but the impact of the effort on trade has been less clear cut as the number of attacks on shipping increased following the operation's launch, while fewer ships were hijacked (from one in three attacked to approximately one in ten). The MSC register has also helped. On the other hand, the pirates have expanded the radius of their operations and acquired modern equipment. Pirates who are apprehended can be arrested in the high seas and territorial waters of Somalia and then transferred either to the flag state or to a third state participating in Atalanta, or to 
another state. Weber (2009) has rightly suggested that Atalanta does not offer a long-term solution to the piracy issue, as it only addresses the symptoms and not the root causes of the problem.

With a view to strengthening the Somali security forces, to stabilize the security situation in that country and to help with state building, the EU launched a military training mission in April 2010. EUTM Somalia provides specific military training of 2,000 Somali recruits. The mission is being conducted in tandem with the Transitional Federal Government and in cooperation with the UN, AMISOM and the USA. EUTM had approximately 150 personnel from 14 member states and a budget of 5 million Euros for one year. Training operations occurred in Uganda.

Even as it has pursued EUTM and Atalanta the Union has budgeted approximately 215 million Euros for development for Somalia for 2008-2013. The main areas of cooperation are governance, rural development and education. EU humanitarian aid in 2008 alone totalled 46 million Euros. The Stability Instrument has also assisted with projects related to critical maritime routes (creation of a regional information centre in Yemen and a regional training centre in Djibouti).

To sum up, ESDP operations in Africa have been concentrated in and around the DR Congo, Sudan and Somalia. These three countries can be seen as a "cluster" for EU engagement in Africa. There are certainly several factors behind this concentration of efforts, such as the intensity of the conflicts addressed, historical legacies and EU and member states interests. Two positive features of these missions considered together stand out. First, the fact that the EU engaged in these countries in different forms is indicative of its broad-gauged approach as it attempted to react to a variety of situations with developing, adapting and combining a number of intervention instruments. Second, the EU ensured a long-term presence with more than one operation thereby suggesting its political commitment and will to secure a sustainable stabilisation in these countries.

\section{ESDP Evolution and the EU comprehensive Approach}

The analysis turns now to the questions asked in the introduction, with a view to assessing whether the EU has advanced as a peace actor in the first decade of ESDP operations and, in particular, whether progress has occurred in support of the comprehensive EU approach to peace building. Institutional differences between the Community and the CFSP/ESDP policy instruments (referred to also as first and second pillars respectively in the academic literature) complicated working together in a comprehensive way, but progress in doing so has developed during the decade. As far as process is concerned, the Commission has been fully associated with ESDP according to the Treaty on European Union. In practical terms, the Commission has regularly participated in meetings of the EU Military Committee since Spring 2005. It also began to second officials to the civil-military cell within the EU Military Staff that same year. It has also been systematically associated with crisis management operations from their initial stages (fact finding missions and planning) until their conclusion (lessons learned exercise) starting with EUFOR Chad/CAR.

As indicated, the Commission has accompanied several of the ESDP operations using its own instruments, including the European Community Humanitarian Office (ECHO), the European Development Fund (EDF) and the Instrument for Stability. In the DR Congo Community support targeted the judicial system, security sector reform, the political/election process and CIMIC (civil-military cooperation). EUPOL and EUSEC in DR Congo coordinated well with the bilateral programmes of member states, highlighting another aspect of the comprehensive approach. The different timeframes for action adopted by the Community and EUPOL impeded cooperation in that case. The AU mission AMIS connected with the Darfur conflict was strongly supported through the African Peace Facility (APF); in addition, EU support included training for the UN police mission, humanitarian assistance, and rehabilitation projects to facilitate the return of refugees. In Somalia, APF supported the AU mission AMISOM while the Commission contributed to stabilisation on land through governance, rural development and education projects. Finally, in Guinea-Bissau the EU focused on security sector reform, but regional capacity building to fight illicit drug trafficking also proved an important additional element.

Working with regional and international partners is a declared objective of the EU, albeit not an easy one to achieve. The European Security Strategy (Council of the EU, 2010b), stressed the importance the EU attaches to effective multilateralism and to the central role of the UN in the international system. Cooperation with the UN in crisis management and peace support is therefore a central element in EU action. This aim was formally recognised, too, in the 2003 European Council Joint Declaration on UN-EU Cooperation in Crisis Management and further in the 2007 Joint Statement, calling for cooperation in particular in the areas of planning, training, communication and best practices. Operation Artemis was launched at the express request of the UN and that mission served a bridging function until MONUC could be deployed. EUFOR DR Congo was also launched at 
UN request to assist MONUC during the election process (Note 4). On the other hand, some coordination difficulties occurred between EUPOL and UNPOL. The re-hating of personnel secured a smooth transition from EUFOR Chad/CAR to the UN Mission. EU support to the African Union missions to Sudan (AMIS) and Somalia (AMISOM) was also undertaken in connection with the UN. These initiatives represent clear examples of the significance the EU attaches to multilateralism, local ownership and subsidiarity. Atalanta developed good working relations with the CTF 151 (combined task force) as part of the US Operation Enduring Freedom (OEF) and with the NATO operation Ocean Shield as well as with many other actors deployed in the area including Russia, China, India and Japan (Weiler, Larik 2010).

With respect to capability development, initial work on military capabilities for crisis operations revealed that the Union suffered from major shortfalls in strategic and tactical airlift, command and control and intelligence assets. The European Defence Agency (EDA), created in 2004 to support member states to improve capabilities in support of ESDP, launched a process leading to the Capability Development Plan (CDP); one of the work strands that inform the CDP is lessons identified from (completed or ongoing) crisis management operations. The EDA Steering Board endorsed the first CDP in July 2008. It identified 12 priority areas, including helicopter availability. (EDA 2010) This is in fact a major shortfall, as evidenced, for example, by the EUFOR Chad/CAR, which was facilitated by Russia's participation with 4 helicopters. Given that similar shortfalls exist within NATO, the Union has identified helicopter availability as a first case for practical cooperation between the EU and NATO in the area of capabilities. The first autonomous (i.e., without recourse to NATO assets) military ESDP operation, Artemis, served as a model for the battle group concept. Battle groups have since become a major driver for developing deployable capabilities among several member states. Battle groups have actually not been deployed, but the experience gathered in putting together rapidly deployable force packages with all necessary transport, communication and logistics elements, including joint training and exercises, enhances the possibilities for the EU to act quickly in the face of crises in the future. In addition, the call for battle groups provides an incentive to member states to increase the rapid deployability of their armed forces (Note 5).

\section{Broader Policy Context}

Crisis management cannot be examined in isolation. It is part of a broader context of challenges and policy actions, including the relationship between development and security. The 2003 European Security Strategy, the 2005 European Consensus on Development and the 2008 Implementation Report, have all argued that sustainable development cannot occur without peace and security. Conversely, without development and poverty reduction, sustainable peace is unlikely to occur. (Council of the EU, 2010b) Indeed the key goals of the 2005 European Consensus on Development linking security and development were:

a) Sustainable development, integration into the world economy, poverty eradication

b) Peace, international security, international cooperation

c) Democracy and rule of law, human rights and fundamental freedoms.

Tocci has proposed a general framework for analysing EU action in peace building (forthcoming). She offers a useful distinction between action aimed at capacity building for specific groups or actors on the one hand and efforts to create incentives for stakeholders, conflict parties and local actors to change their existing behaviour on the other. The mechanisms used to provide incentives include socialisation, conditionality and passive enforcement. The effectiveness of these strategies depends in large measure on their perceived potential value to targeted stakeholders and on EU credibility when offering them. While it is not possible, at least at this stage, to provide a thorough analysis of EU actions according to this framework, it seems fair to contend that they have focused primarily on capacity building, as clearly shown in the case of EU relations with the African Union (Vervaeke forthcoming).

While Tocci offers a general framework for the analysis of EU crisis operations, Darmuzey (forthcoming) has usefully distinguished three categories of EU external assistance instruments: a) crisis/disaster response, including the Stability Instrument, humanitarian assistance (ECHO) and the civil protection mechanism; b) medium and long-term instruments such as development aid, macro-financial assistance, trade etc., and c) CFSP/ESDP (crisis management).

The main challenges for the Union include: a) ensuring a whole of the Union approach despite specific programmatic features; b) taking steps to encourage state building as an endogenous process, in a way that includes not only state institutions but also local administration, civil society and media; security and rule of law are core functions which links with security sector reform; c) acting to address vulnerability and enhance resilience related to climate change, food and fuel shocks, financial/economic crisis; d) working assiduously to 
secure the effectiveness of development assistance; e) developing relevant partnerships with international government organizations (such as Commission/UN Development Programme/World Bank to conduct post-crisis assessments and recovery planning; Commission/UNDP cooperation on electoral assistance; EU-AU Partnerships on peace and security, and on democratic governance and human rights).

Coherence in the use of EU instruments is a necessary but not a sufficient condition for the EU to exert influence on developments on the ground; and coherence needs time to materialise given that action in different policy areas follows a different logic and can only be gradually adjusted. EU crisis management in Africa has shown positive results in terms of coherence; but the concerted approach of relevant EU actors needs to be inscribed into a common diplomatic perspective which the creation of the European External Action Service (EEAS) is expected to facilitate (Helly, 2010).

\section{Conclusions}

This analysis has explored whether the EU has advanced as a peace actor in the course of ten years of ESDP and, in particular, whether progress has occurred in the development of a comprehensive approach to peace building. As in other policy areas of European integration, ESDP can fairly be described as learning by doing. While the picture painted here was mixed, it seems fair to say that member states and EU institutions have made significant progress in working together with the common purpose of enabling the EU to take a part in responsibility of the international community for conflict prevention, crisis management and post conflict stabilisation in Africa (and elsewhere). A number of challenges still exist and call for further common efforts, but the valuable experience gathered so far will be of great help in making the next steps towards consolidating EU "actorness" in this vital field. In particular, the systematic 'lessons learned' process introduced for ESDP operations as well as the linking of such lessons learned to the necessary capability development are positive features whose beneficial effects will likely continue to grow in the future.

\section{References}

Anderson, S. B. (2008). Crafting EU Security Policy. In Pursuit of a European Identity. Lynne Rienner, Boulder.

Berg, P. (2009). EUFOR Tchad/RCA: The EU serving French interests. In M. Asseburg, R. Kempin (Eds.), The EU as a strategic actor in the realm of security and defence, A systematic assessment of ESDP missions and operations, SWP (Stiftung Wissenschaft und Politik) Research Paper 14, Berlin.

Chardon, S. (forthcoming). The exploitation of natural resources and the Kimberley process. In S. Blockmans, J. Wouters, \& T. Ruys (Eds.), The European Union and Peacebuilding: Policy and Legal Aspects.

Christou, G., Croft, S., Ceccorulli, M., \& Lucarelli, S. (2010). European Union security governance: putting the 'security' back. European Security, 19(3), 341-359. http://dx.doi.org/10.1080/09662839.2010.526109

Clément, C. (2009). The EU mission to provide advice and assistance to security sector reform in the Democratic Republic of Congo (EUSEC RD Congo). In G. Grevi, D. Helly, \& D. Keohane (Eds.), European Security and Defence Policy, The first 10 years (1999-2009). European Union Institute for Security Studies, Paris.

Council of the EU. (2010a). Retrieved from http://www.consilium.europa.eu/showPage.aspx?id=268\&lang=en

Council of the EU. (2010b). Retrieved from http://consilium.europa.eu/showPage.aspx?id=268\&lang=EN

Darmuzey, P. (forthcoming). Meeting the challenges of state building: EU development policy and cooperation in post-conflict countries. In S. Blockmans, J. Wouters, \& T. Ruys (Eds.), The European Union and Peacebuilding: Policy and Legal Aspects.

Deutsch, K. et al. (1957). Political Community and the North Atlantic Area, Princeton.

European Defence Agency (EDA), Annual Report 2009, Brussels 2010. Retrieved from http://www.eda.europa.eu/

European External Action Service (EEAS), Instrument for Stability 2010. Retrieved from http://eeas.europa.eu/ifs/index_en.htm

European Parliament. (2008). Options for the EU to support the African Peace and Security Architecture. Directorate General External Policies of the Union, Security and Defence.

European Report on Development. (2010). Retrieved from http://ec.europa.eu/europeaid/multimedia/publications/documents/annual-reports/europeaid_annual_report_ 2010_highlights_en.pdf 
Franke, B. (2009). The European Union supporting actions to the African Union missions in Sudan (AMIS) and Somalia (AMISOM). In G. Grevi, D. Helly, \& D. Keohane (Eds.), European Security and Defence Policy, The first 10 years (1999-2009). European Union Institute for Security Studies, Paris.

Grevi, G., Helly D., \& Keohane, D. (Eds.). (2009). European Security and Defence Policy, The first 10 years (1999-2009). European Union Institute for Security Studies, Paris.

Helly, D. (2010). L'UE et l'Afrique: les défis de la cohérence, EU ISS Chaillot Paper 123. Retrieved from http://www.iss.europa.eu/nc/actualites/actualite/news/back/article/lue-et-lafrique-les-defis-de-la-coherence/

Helly, D. (2009a). The EU military operation in DR Congo (Artemis). In G. Grevi, D. Helly, \& D. Keohane (Eds.), European Security and Defence Policy, The first 10 years (1999-2009). European Union Institute for Security Studies, Paris

Helly, D. (2009b). The EU military operation in the Republic of Chad and in the Central African Republic (Operation EUFOR Tchad/RCA). In G. Grevi, D. Helly, \& D. Keohane (Eds.), European Security and Defence Policy, The first 10 years (1999-2009). European Union Institute for Security Studies, Paris.

Helly, D., (2009c). The EU mission in support of Security Sector Reform in Guinea-Bissau (EU SSR Guinea-Bissau). In G. Grevi, D. Helly, \& D. Keohane (Eds.), European Security and Defence Policy, The first 10 years (1999-2009). European Union Institute for Security Studies, Paris.

Helly, D. (2009d). The EU military operation Atalanta. In G. Grevi, D. Helly, \& D. Keohane (Eds.), European Security and Defence Policy, The first 10 years (1999-2009). European Union Institute for Security Studies, Paris

Howorth J. (2007). Security and Defence Policy in the European Union, Palgrave.

Major, C. (2009). The military operation EUFOR RD Congo 2006. In G. Grevi, D. Helly, \& D. Keohane (Eds.), European Security and Defence Policy, The first 10 years (1999-2009). European Union Institute for Security Studies, Paris

Martinelli, M. (forthcoming). Strengthening security, building peace: The EU in the Democratic Republic of Congo. In S. Blockmans, J. Wouters, \& T. Ruys (Eds.), The European Union and Peacebuilding: Policy and Legal Aspects.

Revelas, K. (2009). L'aspect communautaire dans le capacitaire, in: Pierre Pascallon et André Dumoulin. Quelle politique de sécurité et de défense pour l'Europe? (pp. 73-76). Paris.

Tocci, N. (forthcoming). The EU as a peacebuilder: actorness, potential and limits. In S. Blockmans, J. Wouters, \& T. Ruys (Eds.), The European Union and Peacebuilding: Policy and Legal Aspects.

Tull, D. M. (2009). EUFOR RD Congo: A success, but not a model. In M. Asseburg, \& R. Kempin (Eds.), The $E U$ as a strategic actor in the realm of security and defence, A systematic assessment of ESDP missions and operations. SWP (Stiftung Wissenschaft und Politik) Research Paper 14, Berlin.

Vervaeke, K. (forthcoming). Cooperation between the EU and the AU in the field of peacebuilding, In S. Blockmans, J. Wouters, \& T. Ruys (Eds.), The European Union and Peacebuilding: Policy and Legal Aspects.

Vircoulon, T. (2009). The EU police mission in Kinshasa-DRC (EUPOL Kinshasa) and the EU police mission in RD Congo (EUPOL RD Congo). In G. Grevi, D. Helly, \& D. Keohane (Eds.), European Security and Defence Policy, The first 10 years (1999-2009). European Union Institute for Security Studies, Paris.

Weber, A. (2009). EU naval operation in the Gulf of Aden (EU NAVFOR Atalanta): Problem unsolved, piracy increasing, causes remain. In M. Asseburg \& R. Kempin (Eds.), The EU as a strategic actor in the realm of security and defence, A systematic assessment of ESDP missions and operations. SWP (Stiftung Wissenschaft und Politik) Research Paper 14, Berlin.

Weiler, Q., \& Larik, J. (2010). Going naval in troubled waters: The EU, China and the Fight against Piracy off the Coast of Somalia. The EU and China: Partners or Competitors in Africa?

\section{Notes}

Note 1. The Lisbon Treaty (entered into force on 1 December 2009) refers henceforth to Common Security and Defence Policy (CSDP). 
Note 2. While civilian ESDP missions are funded through the CFSP budget, the cost of military operations is borne to a very large extent by the contributing countries according to the principle 'costs lie where they fall' except for specifically agreed 'common costs' (commonly defined on a case by case basis) and funded through the Athena mechanism to which the member states contribute; common costs typically correspond to $10 \%$ of the overall costs.

Note 3. Tull (2009).broadly shares this assessment. However, it is arguable that the many different EU actions do not amount to an EU strategy and that EU interest evaporated after the elections. Coordination with the UN on SSR also proved difficult. Thus, the mission was a success, but not a model.

Note 4. This assessment depends on the precise definition of the concept; were « true effective multilateralism » to be defined as the EU acting as a bloc in support and as a part of UN operations, this experience would not qualify.

Note 5. The European Commission's legislative and policy work to develop the European defence industry, research and technology in the security field as well as space policy also contributes to capability development. See, for example, Revelas 2009.

\section{Endnote}

The manuscript was completed effectively at end 2010. Since then major developments in the area of CSDP deployments as well as military interventions in Africa have occurred. Since it was not possible to thoroughly rework the paper to take account of and do justice to these developments, a brief reference should suffice at this point.

The EU has adopted a number of strategy documents confirming the comprehensive approach and highlighting the regional dimension:

- Strategy for Security and Development in the Sahel, adopted in March 2011

- Comprehensive Approach to Sudan and South Sudan, adopted in June 2011

- Strategic Framework for the Horn of Africa, adopted in November 2011

Several new CSDP operations have been launched reflecting and implementing the comprehensive and regional approach:

- EUCAP Sahel Niger, launched in August 2012, is a civilian CSDP mission focused on training, mentoring, providing advice and assistance to improve the capacities of the security forces (gendarmerie, national police, national guard) of Niger

- EUAVSEC South Sudan, started in September 2012, is a civilian CSDP mission to strengthen aviation security at Juba international airport following the independence of the country in July 2011, and providing advice, mentoring, technical assistance and training

- EUCAP Nestor for regional maritime capacity building for the Horn of Africa and the Western Indian Ocean, is a civilian CSDP mission deployed as from September 2012, to enhance maritime capacities of initially four countries in the region (Somalia, Djibouti, Kenya, Seychelles, to be extended to Tanzania as soon as possible) and complementing EUNAVFOR Atalanta and EUTM Somalia

- EUTM Mali is a military training mission launched in February 2013 with 22 EU member states contributing personnel in order to train and advise the Malian armed forces as part of the effort to restore constitutional order and state authority as well as law and order throughout the country.

During the same period, EU member states have initiated and/or participated in military operations:

- in Libya in 2011 following adoption of UNSC Resolution 1973 (five EU member states, France, UK, Italy, Belgium, Denmark together with the US, Canada, Norway)

- in Mali France launched in January 2013 operation Serval at the request of the Malian authorities.

\section{Copyrights}

Copyright for this article is retained by the author(s), with first publication rights granted to the journal.

This is an open-access article distributed under the terms and conditions of the Creative Commons Attribution license (http://creativecommons.org/licenses/by/3.0/). 